lations as his should have deterred his contemporaries from following his trend of thought or paying much attention to him. It cannot be claimed that he preceded Dalton in his conception of the Atomic Theory, but Richter belongs to the number of the great original thinkers of chemistry and it is time that greater justice be done him.

F. P. Venable.

\section{VERTEBRAL FORMULA OF DIPLODOCUS} (MARSH).

The splendid skeleton of Diplodocus, discovered in the Como Bluffs of Wyoming by the American Museum party of 1897, has enabled Professor Osborn to very materially increase our knowledge of the osteology of that genus.* Interesting and unique as was the material that formed the basis of Professor Osborn's memoir, it nevertheless left many questions unsettled concerning the osteology of Diplodocus. In 1899 a second skeleton was discovered in the Dinosaur beds of the Upper Jurassic, near Sheep Creek, in Albany County, Wyoming, by Dr. J. L. Wortman, while engaged as Curator of Vertebrate Paleontology of this Museum, in exploring the fossil-bearing horizons of that region.

The second skeleton of Diplodocus was very carefully exhumed under the skillful direction of Dr. Wortman, and has since been entirely freed from the matrix and temporarily mounted by Mr. A. S. Coggeshall, Chief P'reparator in the Department of Paleontology.

Now that this material is available for study, it proves to supplement in a remarkable manner the skeleton belonging to the American Museum. A detailed description of our material will be given in a paper by the writer which it is proposed to have appear among the memoirs of this institution. In the present note only the

* See 'A Skeleton of Diplodocus,' Part V., Vol. I., Mem. Am. Mus. Nat. Hist., pp. 191-214 vertebral column will be considered, and no attempt will be made to describe this in detail, but rather to correct some errors concerning the vertebral formula of Diplodocus as given by Osborn in his memoir cited above, and by Dr. W. J. Holland, in a subsequent paper entitled 'The Vertebral Formula in Diplodocus, Marsh,' published in this Journal, May 25, 1900, and based upon the material now under discussion.

About 45 feet (14 meters) of the vertebral column is preserved in our specimen. When discovered the vertebræ did not lie in a connected and unbroken series, yet there can be little doubt that they all pertain to the same individual, and they have been mounted as a continuous series commencing with the axis and ending with the twelfth caudal. In all 41 vertebræ are represented, including 14 cervicals (all but the atlas), 11 dorsals, 4 sacrals and 12 caudals.

Assuming that no vertebræ are missing from our series the vertebral formula of Diplodocus should now be written as follows :

\section{Cervicals, 15.}

Dorsals, 11.

Sacrals, 4.

Caudals, 37, as estimated by Osborn, not 35, as attributed to him by Holland.

The above vertebral formula will be seen to differ from that given by Holland, the latest contributor on this subject, as follows :

1. The number of cervicals is at least 15 .

2. There are 11 dorsals instead of 10 , as fixed by Holland, who mistook the first presacral of Osborn for a sacral.

There are 4 sacrals, as given by Osborn and Holland, while the number of caudals is still placed at 37, as estimated by Osborn. Of the caudals, only the 12 anterior are preserved in our skeleton, and the second and third of these have coossified centra.

In placing the number of dorsals at $11, I$ am assuming that Osborn is right in considering the first vertebra with a free spine, 
anterior to the 3 sacral vertebræ with coalesced spines as a dorsal rather than a sacral. I also assume that we have represented in our skeleton the complete dorsal series, but of this we cannot be absolutely certain, since the vertebræ were not found in an articulated series. Unfortunately no diagram was made, at the time of exhuming the remains, showing the relative position of each of the vertebræ in the quarry. Early last spring, at the request of the writer, Mr. W. H. Reed (who assisted in unearthing the skeleton), while again on the ground, made a diagram of the quarry, showing the relative positions, as he remembered them, of the various bones of the skeleton. This diagram shows two rather marked breaks in the vertebral column, and I may add that a close examina. tion of the dorsal series as now mounted seems to indicate that there are two or more missing vertebræ. This is especially noticeable between presacrals 7 and 8 or dorsals 5 and 4 . In presacral 7 , the capitular facet is situated well up, on the side of the neural arch, while in the presacral im. mediately anterior it extends well down on the centrum. Not only does this sudden shifting of the position of this articular surface seem to indicate that there are wanting at this point in the series one or more vertebræ, but I may add that according to Professor Osborn's figures the actual position of the capitular facet on presacral 8 is much higher than that occupied by that facet on the vertebra that has been assigned to the same position in our series, thus indicating a more anterior position for this vertebra, and consequently a greater number of dorsal vertebræ than has been given above. Since the vertebræ in the American Museum series were all found interarticulated by their zygapophyses, there can be no question of the position of each dorsal in that series, relative to the sacrum. There also appears to be a break in our series between the last cervical and the first dorsal, and it is barely possible that the first true dorsal or last cervical is wanting in our series. From the above it will be seen that there is a possibility that when the actual number of dorsal vertebræ in Diplodocus is definitely known, it will be somewhat greater than that given here, and that Professor Marsh was perhaps not far wrong when he figured it at 14.

Should the first vertebra anterior to the three sacral vertebræ with coalesced spines come eventually to be considered as a sacral, rather than a dorsal, the sacrum would then have to be considered as composed of 5 vertebræ instead of 4 , as has been done by Osborn, Holland and the present writer. If we consider this vertebra as a modified dorsal and not a sacral, there would seem to be no good reason why we should not consider the fourth sacral, which also has a free spine, as a modified caudal, since the centra of each are firmly ankylosed with the sacrals bearing coössified spines. This interpretation would reduce the number of true sacrals to 3 , as was originally given by Marsh.

Another marked character brought out by our skeleton is the great absolute and proportionate length of the cervical region in Diplodocus. Osborn has given the known and estimated lengths of the vertebral column as follows :

Caudals, 30 feet.

Sacrals, 2 feet.

Dorsals (estimated) 12 feet.

Cervicals (estimated) 12 feet.

Skull, 2 feet.

The length of the cervical series alone in our skeleton is somewhat over 21 feet; and the atlas is yet to be found. The dorsal series is somewhat shorter than that estimated by Osborn.

The main points that it is desired to emphasize are :

1. The number of cervical vertebræ in Diplodocus is definitely fixed at at least 15 . 
2. There are at least 11 dorsal vertebræ, perhaps two or three more.

3. The great comparative and absolute length (21 feet) of the cervical series, a striking analogy to that exhibited in the struthious birds.

4. The actual number of dorsals in Diplodocus seems to be 11 , but cannot be definitely determined from our skeleton, and we must await further discoveries for its solution.

Carnegie Museum.

J. B. HATCHER.

PLANT GEOGRAPHY OF NORTH AMERICA. III.

THE LOWER AUSTRAL ELEMENT IN THE FLORA

OF THE SOUTHERN APPALACHIAN REGION. A PRELIMINARY NOTE.*

IN that portion of the United States which lies south of the Potomac and Ohio Rivers and east of the Mississippi, three principal orographical areas are readily distinguishable. Th́ese are generally known as the Pine Barren or Low Country (Coastal Plain), the Piedmont or Middle Country and the Mountains or Upper Country. Their respective characteristics-climatic, physiographical and biological-have been so often described in popular and scientific writings that to enumerate them here would be superfluous. So obvious are their distinguishing features, that no observant traveler fails to take note of them as he crosses the southeastern States.

The altitudinal limits of these three areas coincide roughly with those of three great continental life zones, $i$. e., the Lower Aus-

* In the matter of nomenclature, in this paper, I have followed that employed by Britton and Brown in their 'Illustrated Flora of the Northern United States and Canada.' But in order to be understood by readers who are not familiar with that nomenclature, I have added, in parentheses, the synonym generally current among American botanists before the adoption of the 'Rochester Code,' wherever a change has been made under that code. tral Zone in its humid or Austro-riparian Area; the Carolinian Area of the Upper Austral, and the Alleghanian Area of the Transition Zone.*

The Coastal Plain, presenting but scant diversity in its orography, is occupied almost exclusively by a Lower Austral fauna and flora. In the Piedmont Region the surface of the country is less uniform and we encounter within its general boundaries many scattered localities where conditions permit the occurrence of Lower Austral or of Transition colonies amid the prevailing Carolinian life. But in the Mountain Region there exists such a variety of conditions that all the life zones from Lower Austral to Hudsonian are represented in places, although their limits are here very ill-defined, and the precise location of them presents many intricate problems.

Thus along the higher Smoky Mountains and the Blue Ridge, we find a typically Canadian forest of firs (Abies Fraseri), accompanied by such trees and shrubs as the yellow birch (Betula lutea), mountain ash (Sorbus americana), mountain maple (Acer spicatum), red elder (Sambucus racemosa) and wild red cherry (Prunus pennsylvanica). Other characteristically Canadian species like the striped maple (Acer pennsylvanicum), hemlock (Tsuga canadensis), white pine (Pinus Strobus) and the arbor vitæ (Thuya occidentalis) descend to much lower elevations (900 meters or less). Along the crest of the highest mountains of this region, usually at an altitude of 1,800 meters (6,000 feet) or upwards, a sparse Hudsonian flora is encountered. The green alder (Alnus viridis), and, of herbs, Arenaria groenlandica,

* For a definition and description of these zones see Merriam in Nat. Geogr. Mag., 6 : pp. 220-238, Maps, 1894. Also, 'Life Zones and Crop Zones of the United States' ; Bull. Div. Biol. Survey, U. S. Dept. Agric., 10 : pp. 18-33, Map, 1898 (with a correction of the temperature data), in SoIknCE 9 : No. 212, p. 116 (1899). 